\title{
UTILIZATION OF JAMU IN PUERPERAL MOTHER IN SUMATERA AND JAVA ISLAND (LITERATURE REVIEW OF HEALTH ETHNOGRAPHIC RESEARCH 2012-2016)
}

\author{
Zulfa Auliyati Agustina ${ }^{1}$, Yunita Fitrianti ${ }^{1}$ \\ ${ }^{1}$ UPF Health Technology and Innovation \\ Center of Research and Development of Humanities and Health Management. \\ Jl. Indrapura No.17 Surabaya Indonesia \\ Correspondence Address: Zulfa Auliyati Agustina \\ Email: zoelauliya@gmail.com
}

\begin{abstract}
Indonesian people used to consume herbal medicines called "jamu", which is as a hereditary alternative medicine, to heal or fresh the body. Furthermore, the postpartum mother, who needs recovery after birth, also drinks the herbs. This essay employed a literature review of 14 ethnographic books conducted by National Institute of Health Research and Development, which focused on the herbal medicines for puerperal mothers. The results of the literature review revealed that the majority of mothers in Java and Sumatera using jamu during the postpartum period to heal and recover the mother's health. Not only do the mother drink jamu, but she also applies certain herbs on her body. Clinical trials have proved the efficacy of ingredients for herbal medicines. Therefore, people prefer to use the herbs because it is easy to find and inexpensive, and it also has a long-term effect on the mother's health and fitness. However, herbal medicine, which is usually employed by the people, needs further research, in particular, the dose of jamu. So, herbal medicine based on local wisdom can be one of consideration in the health development program.
\end{abstract}

Keyword: Jamu, Pueperal, Traditional

\section{ABSTRAK}

Masyarakat Indonesia umumnya menggunakan obat-obatan herbal yang disebut "jamu". Jamu merupakan obat alternatif turun-temurun, untuk menyembuhkan atau menyegarkan tubuh. Lebih lanjut, ibu nifas yang membutuhkan pemulihan setelah lahir, juga meminum ramuan itu. Artikel merupakan literature review dari 14 manuskrip hasil riset etnografi yang dilakukan oleh Badan Penelitian dan Pengembangan Kesehatan, yang berfokus pada obat-obatan herbal untuk ibu nifas. Hasil review menunjukkan bahwa mayoritas ibu di Jawa dan Sumatera menggunakan jaтu pada masa postpartum untuk menyembuhkan dan memulihkan kesehatan. Ibu bersalin tidak hanya meminum jamu, tetapi ia juga menggunakan ramuan tertentu pada tubuhnya. Uji klinis telah membuktikan khasiat tanaman obat. Karena itu, masyarakat lebih suka menggunakan herbal karena mudah ditemukan, murah dan memiliki efek jangka panjang pada kesehatan dan kebugaran ibu. Namun, obat herbal yang biasanya digunakan oleh masyarakat perlu penelitian lebih lanjut khususnya dosis jamu. Sehingga jamu bisa menjadi salah satu alternative perawatan dalam program pengembangan kesehatan.

Kata kunci: Jamu, Nifas, Tradisional

\section{INTRODUCTION}

Jamu is a medicine made from the roots, leaves and so on (KBBI, 2018), while the definition according to the regulation of the Minister of Health No 003/Menkes/Per/I/2010 Year 2010 about the study of Jamu in service-based research Health, Jamu is a traditional Indonesian medicine derived from ingredients or herb ingredients that are in the form of plant material, veterinary material, mineral material, Sarian preparations, or a mixture of such substances that are hereditary used for Treatment, and can be applied in accordance with the prevailing norms in the Community (Ministry of Health, 2010).

In Indonesia, Jamu is part of the culture and heritage of ancestors used in generations since hundreds of years ago. It is not known exactly the beginning, but in Borobudur temple there are two reliefs depicting the activity of making jamu. Indonesia has about 25,000-30,000 species 
of plants and is inhabited around 300-700 ethnic groups. These ethnic plants have been converted to various purposes, one of which is for the purpose of treatment (Silalahi, 2017). Indonesia is a developing country where one of the its is the dominance of traditional elements in the lives of everyday society. Diversity of biological wealth becomes a supporting element in the tradition of life, one of which is the utilization of plants as a medicinal ingredient by various ethnic groups (Rahayu et al., 2006). According to the Executive Secretary of the Central Asian agricultural and Food Science and Technology Development Center (SEAFAST), there are 30 plants in Indonesia where 7 thousand of them have been exploited as traditional medicine (Budi, 2016).

Riskesdas Data 2013 shows that $30.4 \%$ of households in Indonesia have been utilizing traditional health services and one of the services used by households by $49 \%$ is a type of herb. The province that utilizes many herbs is East Java (65\%), IN Yogyakarta (58.1\%) and Papua (55.7\%) (Ministry of Health, 2014). The utilization of Jamu that is part of traditional medicine is closely related to the growing culture in the local community (Rahayu et al., 2006).

The use of Jamu in the community is very broad, one of it is for maternity care. After childbirth, it is necessary to restore the physical condition of a mother. Jamu is one of the alternatives in recovery of the energy of a mother. Childbirth is a welcome event that welcomes new family members who are very awaited as a special concern for the whole family. Various preparations are carried out since the period of pregnancy with the aim that the process of childbirth and mothers and babies survived (Efendi, Permana and Astuti, 2015).

Why people use Jamu in their daily life. First, the management of Jamu is very easy, cheap, and supported by many types of medicinal plants that grow in Indonesia. Recorded $70 \%-80 \%$ of people in Java
Island have a habit of drinking herbs including for the treatment of Nifas because of the ease of obtaining, more economical and potent (Ratih Sari Prastiwi, 2018)(Triratnawati, 2010). Secondly, the absence of dissatisfaction with modern medicine. It is like a study conducted by Green (2006) About Chinese migrants in the UK who are still looking for traditional medicine and Chinese herbal remedies because it is not satisfied with modern medicine (Green et al., 2006). It is also supported by the difference of healthy concept and pain in various ethnic groups, whereas according to Kalangie (1994), the knowledge and belief of the people about illness is one component of the search for treatment (Kalangie, 1994).

\section{METHODS}

The writing of this article uses a literary review method or a literature review to explain the phenomenon and study of previous research, digging the linkage between the research being done with what has been done (Chariri, 2009). Subsequently, the data was analyzed descriptively and explained in order to be understood

The review literature was conducted against 14 manuscripts with the focus on the problem of jamu utilization for the Mother Nifas Health Ethnography Research (REK) conducted in 2012-2016 by the Ministry of Health. Furthermore, the 14 manuscripts of the REK results are limited to the results of the research in Java and Sumatra so as to produce 5 manuscripts to be analyzed more deeply. This article discusses the characteristics of the region, management and efficacy and community perspectives on herbs.

Health ethnography research has obtained the ethics approval of the Ethics commission of Health Research body $\mathrm{R}$ \&amp; D Health Ministries Ministry of Health. TO. 01.05/EC/393/2012 Year 2012 for ethnic Gayo, Java and Madura and 
number LB. 02.01/5.2/KE. 194/2015 year 2015 for coastal and Sunda ethnic.

\section{RESULT}

\section{Region Characteristics}

The Institute of Health Research and Development through Center of Research and Development of Humanity and Health Management has been carrying out a culture-based health Ethnography (REK) research from 2012 to 2016. Research has been implemented in 81 ethnic groups scattered throughout Indonesia as in the table below

Table 1. Number of ethnic research location REK year 2012-2016

\begin{tabular}{cc}
\hline Year & $\begin{array}{c}\text { Number of ethnic } \\
\text { research locations }\end{array}$ \\
\hline 2012 & 12 Ethnic \\
2014 & 20 Ethnic \\
2015 & 29 Ethnic \\
2016 & 20 Ethnic \\
\hline Total & 81 Ethnic
\end{tabular}

Source: Health Ethnography Research year 20122016

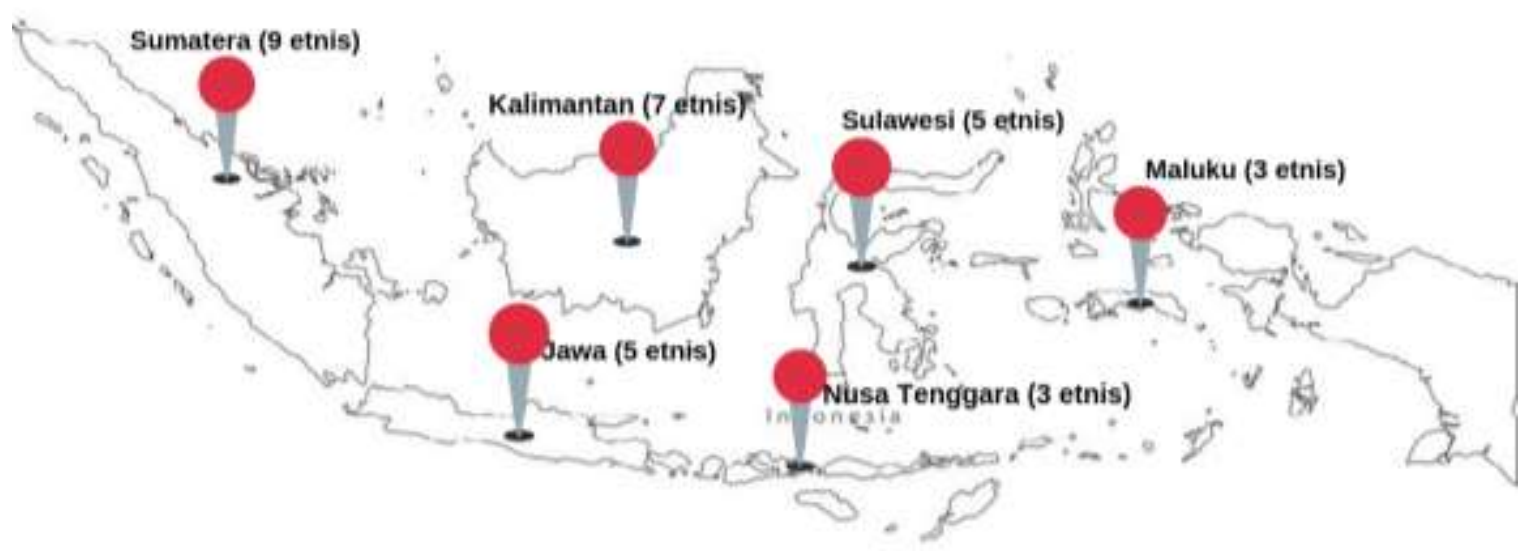

Figure 1. Number of ethnic herbs utilizing regional medicine year 2012-2016

In 2012, the REK theme was maternal and child Health (KIA), so the entire book was produced themed about KIA. While the following years the theme of research began to vary according to the health problems found in the ethnicity.

Each ethnic at the research site has its own distinctive cultural features. In terms of childbirth and the utilization of herbs for the treatment of mother Nifaspun diverse. In 2012, out of 12 ethnic research locations recorded 7 ethnicities (58\%) That utilize jamu for the NIFAS time treatment process. Year 2014 recorded 12 ethnicities (60\%) Utilizing Jamu for the mother of Nifas, in 2015 there were 12 ethnicities $(41 \%)$ That utilizes Jamu Nifas and in 2016 only 1 ethnicity that utilizes herbs for the treatment of Nifas. The overall recorded 32 ethnicities are utilizing herbal medicine in the care of Mother Nifas.
Figure 1 shows that from 32 ethnic research locations REK, Sumatra, Kalimantan, Java and Sulawesi are the most locations of REK implementation from 2012 to 2016. Based on the results of Riskesdas year 2013, Java and Sumatera Island are regional with the highest utilization of traditional health services, so the discussion of the utilization of Jamu Nifas focused on the 2 regional.

Based on table 2, not all ethnic groups in Sumatera and Java are utilizing medicinal herbs for the care of the mother Nifas. Of the 9 ethnic locations of research in Sumatera region that utilize Jamu for Mother Nifas, only 2 ethnic who utilize Jamu to restore energy and maternal health after childbirth. As for the Java region there are 3 ethnic, namely Java, Madura and Sunda, which utilize the herb herbs to restore maternal health after childbirth. 
Ethnic use herbal medicine after maternity is listed in table 2. Gayo ethnic, coastal, Java Bantul, Madura and Sunda use Jamu to restore energy and maternal health. Other ethnic groups in Sumatra and
Java use herbs to accelerate wound healing, clean up dirty blood, slimming and to prevent the possibility of other diseases that arise after childbirth.

Table 2. The use of herbal medicine recovery by Regional and ethnic Nifas

\begin{tabular}{|c|c|c|c|c|}
\hline \multirow[t]{2}{*}{ Regional } & \multirow[t]{2}{*}{ District } & \multirow[t]{2}{*}{ Ethnic } & \multicolumn{2}{|c|}{$\begin{array}{c}\text { Jamu Health Recovery } \\
\text { Mother Nifas }\end{array}$} \\
\hline & & & Yes & No \\
\hline \multirow[t]{10}{*}{ Sumatera } & Gayo Lues & Gayo & $\sqrt{ }$ & \\
\hline & Aceh Barat & Aceh & & $\sqrt{ }$ \\
\hline & Indragiri Hilir & Laut & & $\sqrt{ }$ \\
\hline & Mentawai & Mentawai & & $\sqrt{ }$ \\
\hline & Musi Banyuasin & Anak Dalam & & $\sqrt{ }$ \\
\hline & Sarolangun & Melayu Jambi & & $\sqrt{ }$ \\
\hline & Ogan Komering Ulu & & & $\sqrt{ }$ \\
\hline & Selatan & Daya & & \\
\hline & Pasaman Barat & Minangkabau & & $\sqrt{ }$ \\
\hline & Tapanuli Tengah & Pesisir & $\sqrt{ }$ & \\
\hline \multirow[t]{5}{*}{ Java } & Bantul & Java & $\sqrt{ }$ & \\
\hline & Sampang & Madura & $\sqrt{ }$ & \\
\hline & Cirebon & Java & & $\sqrt{ }$ \\
\hline & Lebak & Baduy Dalam & & $\sqrt{ }$ \\
\hline & Cianjur & Sunda & $\sqrt{ }$ & \\
\hline
\end{tabular}

\section{How to use and efficacy of Jamu}

Consumption of jamu and Indonesian people are two things that are not separated. People have a different method of consuming herbs.

Various ways to consume jamu is not separated from the traditions and culture implemented by the local community. Jamu consumed by boiled and drunk water, in slices (chopped) eaten directly in the form of chili sauce or vegetables or crushed into a param powder or lullaby games. Composition of herbal ingredients and how to use the acquired community by hereditary from ancestors.
People believe the efficacy of every ingredient and herb consumed. Efficacy obtained by Mrs. Nifas from proper use of jamu.

Table 3 shows the diversity of natural materials utilized by people in Sumatra and Java to restore the health of maternity mothers. Medicinal materials are formulated and used in accordance with the habits of the community.

Turmeric and ginger rhizome is a plant that is mostly used as a ingredient for making jamu in the form of jamu that is consumed by drinking, as well as in the form of param powder that is balbed in the body of post-natal mothers. 
Zulfa Auliyati Agustina dan Yunita Fitrianti, Utilization of Jamu in Puerperal... 97

Table 3. Medicinal plants and how to use them by ethnicity

\begin{tabular}{|c|c|c|c|c|}
\hline Regional & Ethnic & Herb Ingredients & How to Manage & How to use \\
\hline \multirow[t]{2}{*}{ Sumatera } & Gayo & 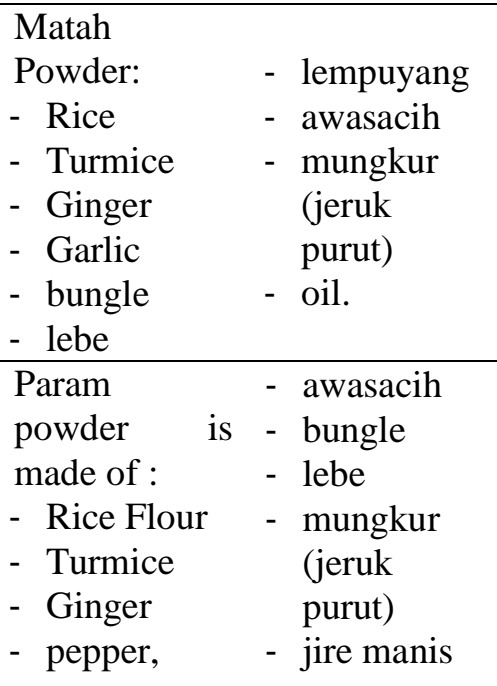 & 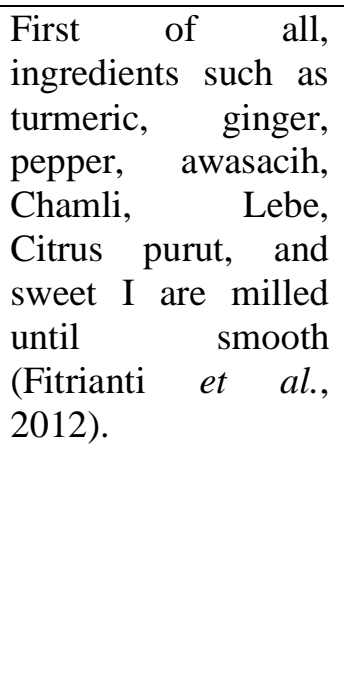 & $\begin{array}{l}\text { Applied to } \\
\text { Body }\end{array}$ \\
\hline & Pesisir & $\begin{array}{l}\text {-First three days: Papaya } \\
\text { leaves, ginger, shallots and } \\
\text { salt. } \\
\text {-The seventh day to the } \\
\text { fourteenth day: The herb } \\
\text { ginger, turmeric, clove, } \\
\text { nutmeg, black pepper and } \\
\text { henna leaves. }\end{array}$ & $\begin{array}{l}\text { The ingredients are } \\
\text { mashed and then } \\
\text { squeezed (Dinata, } \\
\text { Arundita and } \\
\text { Suharmiati, 2015). }\end{array}$ & Drink \\
\hline \multirow[t]{3}{*}{ Java } & $\begin{array}{c}\text { Java } \\
\text { (Bantul) }\end{array}$ & 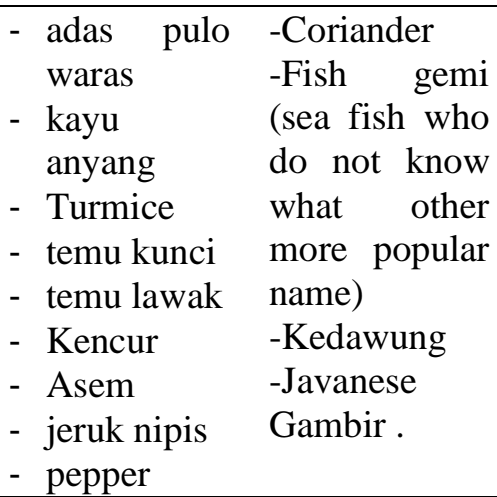 & $\begin{array}{l}\text { All the herbs are } \\
\text { pounded or can also } \\
\text { be blender, filtered } \\
\text { and taken, and then } \\
\text { drunk (Kristiana et } \\
\text { al., 2012) }\end{array}$ & Drink \\
\hline & Madura & $\begin{array}{l}\text { - Young Coconut water } \\
\text { - Jamu package sold in stalls } \\
\text { - Param (Widyasari et al., } \\
\text { 2012) }\end{array}$ & $\begin{array}{l}\text { Param materials } \\
\text { include kencur, } \\
\text { lemongrass, klabet, } \\
\text { ginger }\end{array}$ & $\begin{array}{l}\text { Applied in } \\
\text { abdomen, } \\
\text { waist, face }\end{array}$ \\
\hline & Sunda & $\begin{array}{l}\text {-Leaves Jawer Kotok } \\
\text {-Lime leaves } \\
\text {-Paria leaves } \\
\text {-Semging leaves }\end{array}$ & $\begin{array}{l}\text { Boiled leaves } \\
\text { drinkable } \\
\text { (Purwanto, } \\
\text { and } \text { MJK } \\
2015)\end{array}$ & Drink \\
\hline
\end{tabular}

\section{Community Perspectives on Herbs}

People's lives are very close to the nature and surrounding environment before technology touches human civilization.
The utilization of biological resources for survival and treatment is one part of local wisdom that is strong with cultural values. Local people keep and bequeath the 
traditions in a hereditary even though sometimes not well documented.

Not only the activity of drinking herbs to maintain health or part of the healing efforts, but many cultural perspectives underlying the preservation of herbs. Gayo Society, ACEH assessed that jamu is not merely an attempt to treat illness. But the community argues that in addition to curing, Jamu also provides a long-term healing effect so that maternity mothers are stronger and body stamina is awake.

“... Better medicinal village than medicine doctor. Parents said, because we are working, Menyangkul, gardening, carrying firewood on the back. Indeed medicine Doctor is also quick to make it, but briefly only the time of the kitchen (Nifas only)..., "[KS]

This is because the majority of Gayo community livelihoods are farmers and gardening in the fields. So a mother must be back healthy to be able to work in the fields again. Similarly, the tradition of society in Cianjur West Java. Consuming Jamu after childbirth is a tradition to accelerate the recovery process.

".... here if it has been birth like nyedu drugs traditional herb from leaves like Kotok jawer so that the uterus quickly dry yes if you give birth to the womb like wounds if the same good Kotok jawer fast rotunda plus again same lime leaves So as not to smell and clear blood... " [SH]

\section{DISCUSSION}

\section{Region characteristics}

Indonesia is a country rich in spices and diversity of natural results. Treatment and treatment using herbs, herbs and herbs have been practiced by the community in hereditary. Although Jamu seems to be closely related to Javanese tradition, but almost every region in Indonesia has its distinctive characteristics in the utilization of plants to make traditional ingredients.

The ancient manuscript in Java has recorded a long history of the use of Jamu for treatment. Research on the ups and downs of Jamu making notes that there is a fossil in the island of Java with the form of lumping, Alu and stone which is a tool to make herbal medicine. The relief of Borobudur Temple, notes on the fiber and the Primbon herbal medicine Java is evidence that Jamu is used by people in the island of Java since the era of ancestors (Purwaningsih, 2017)(Mulyani, Widyastuti and Ekowati, 2016).

Riskesdas results (2013) related to public access to health facilities showed that $66.3 \%$ of the public knew the existence of midwives practice and home maternity. The mode of transportation is quite affordable. $63.7 \%$ of people in rural areas walk to the nearest Puskesmas (Ministry of Health, 2014).

The tradition of society in keeping herbal drinking culture is the reason why Jamu is still utilized today. One of jamu utilization is to restore and improve maternal health after passing through the process of childbirth.

\section{How to use and efficacy of Jamu}

It is in line with the results of research on medicinal herbs(RISTOJA) in 2012. Noted 521 herbs are utilized for post-natal treatment, the three most widely used rhizome are turmeric, ginger and kencur (B2P2TOOT, 2012).

Sources of local natural resources and hereditary cultures of local ancestors influence the diversity of the ingredients used by the community. Shanti's research (2014) shows that traditional treatment for women's care in Keraton Surakarta uses 120 plant species. There are 61 types of herbs that are still used for women's treatment. The herb is divided into 17 different usability categories. Application of the herb by drinking and spreadable (Boreh, Lulur, Tapel, Masks) (Shanthi, Jumari and Izzati, 2014).

The results of the research on the use of Jamu for Mother Nifas, showed that the type of jamu consumed varies, there are consumed in the form of pills there are 
also processed herbs that are consumed to maintain endurance (Ratih Sakti Prastiwi, 2018).

The Ethnobotanical review and efficacy test of turmeric has been carried out. Ethanol extracts in turmeric rhizome have been tested at various dosages. The test results showed an anti-inflammatory effect and at high doses $(1000 \mathrm{mg} / \mathrm{kg})$ turmeric was able to suppress the edema to $78 \%$. In addition turmeric also efficacious in restoring stamina or vitality of the body (Rustam, Atmasari and Yanwirasti, 2007)(Elfahmi, Woerdenbag and Kayser, 2014) (B2P2TOOT, 2015).

Ginger demonstrated efficacy as a proven anti-microbial in some research and laboratory tests (Bhargava et al., 2012 in (Royyani et al., 2018)). People use ginger by boiling and drinking, other than that Ginger is also utilized for bath herb. Handayani Research (2012) shows that after childbirth, a mother underwent a ritual that aims to restore the stamina of the mother after childbirth. Mother bathed in warm water from the tub containing the Luli lo lambi (dried banana leaves), bintalo (distance/balacai), Leaf Tapulanga, Goraka (ginger), yellow (turmeric), Onumo, Sulasi, and Herani leaves. The leaves and spices were previously boiled and then mixed with water for bathing (Handayani, 2012).

Research on Jamu for health care mother Nifas in the Tegal area showed that the consumption of herbal medicine for mothers after childbirth issafe for the health ofmother. Composition of Jamu consumed contain several medicinal plants that are able to support the recovery of maternal health such as Kencur and Temu sleigh (Ratih Sakti Prastiwi, 2018). The results of the research ever Sinaga et al. (2011) indicates that the Zingiberaceae people are widely used for medicinal herbs. Rimpang from Zingiberaceae is shown to contain Limonen, Eugenol, and Geraniol and has the efficacy of restoring vitality (Shanthi, Jumari and Izzati, 2014) (B2P2TOOT, 2015).
Kencur is one of the rhizome of medicinal plants that is widely used as a herbal herb for mothers after childbirth. Dayanthi Research (2016) on the extract of Kencur (Kaempferia galanga L.) indicates that there is a tonic efficacy in the kencur to refresh the body and help restore vitality or stamina (Dayanthi, 2016) (B2P2TOOT, 2015).

\section{Community Perspectives on Herbs}

The tradition of consumption of jamu after childbirth in Sundanese people used ways that they believed to be hereditary. In the time of Nifas, a mother is required to drink packets of traditional medicinal herbs or herbs. Jamu is believed to be able to restore womb quickly. In addition, jamu consumption is also beneficial to restore mother's stamina. Not only that, after giving birth a mother will feel aches, hence a series of ritual massage and herbs should be given to refresh the body ((Purwanto, MJK and Soerachman, 2015). Research on the cultural factors of NIFAS treatment suggests that consuming herbs in addition to regulating the distance of pregnancy, also beneficial to restore the body condition such as the original and the body tasted good (Sri Rahayu, Mudatsir and Hasballah, 2017).

The study of traditional medicine in postnatal mothers in Aceh shows that Jamu is not merely the process of using medicinal herbs, but is believed to help the healing process of postnatal mothers, relieving muscle pains and The body feels more stamina so that mothers are stronger carrying out physical activities such as farming, caring for farms and Livestock (Fuadi, 2018). Paryono Research (2014) states that Javanese people use traditional herbs that are inherited from the ancestors for the treatment and prevention of diseases. The community assesses that traditional herbs are generally safer and more potent if formulated according to the recommended dose, easy to obtain, natural and inexpensive compared with modern medicine. In addition to the traditional 
treatment efforts are considered efficacious because it can release social tension. ((Paryono and Kurniarum, 2014) (Triratnawati, 2010) (Sari, 2006).

\section{CONCLUSION}

Maternity mothers in the island of Java and Sumatera still use herbal medicine for post-natal care including to restore energy and stamina of the body lost during childbirth. The processing and use of jamu is very diverse, ranging from jamu drunk, applied to the body or in certain parts. The ingredients of medicinal plants used in the herb are also scientifically proven to be able to restore the energy and stamina of the post-natal labor process. The harvesting of jamu is still sustainable to date one of them because of the value in the community that the treatment with Jamu is easy to obtain and more economical. In the Community view Jamu is a complete treatment that affects the health of long-term mothers. It is expected that there is more research related to the dose of jamu herb used, so that it could be developed by the local culture-based herbal medicine Nifas to support services in health facilities.

\section{REFERENCE}

B2P2TOOT (2012) Laporan Nasional Eksplorasi Pengetahuan Lokal Etnomedisin dan Tumbuhan Obat Berbasis Komunitas di Indonesia (RISTOJA 2012). Tawangmangu.

B2P2TOOT (2015) Eksplorasi Pengetahuan Lokal Etnomedisin dan tumbuhan Obat Berbasis Komunitas di Indonesia (Etnis Osing Provinsi Jawa Timur). Tawangmangu.

Budi, M. (2016) Indonesia Punya 2 Juta lebih Varian Jamu yang Bisa Dikembangkan.

Chariri, A. (2009) Landasan Filsafat dan Metode Penelitian Kualitatif.

Dayanthi, N. P. K. (2016) Uji Klinis
Aktivitas Tonikum dari Ekstrak Rimpang Kencur (Kaempferia galanga L) dengan Metoda Harvard Step Test. Universitas Andalas.

Dinata, A., Arundita, N. N. and Suharmiati (2015) Kesehatan Ibu \& Anak: Dalam Lingkaran Ritual Etnik Pesisir - Kabupaten Tapanuli Tengah. Surabaya: Pusat Humaniora, Kebijakan Kesehatan dan Pemberdayaan Masyarakat.

Efendi, N., Permana, M. and Astuti, W. D. (2015) Belenggu Kayu 'Temau' \& Akar 'Untuyut': Potret Kesehatan Jiwa Di Sei Antu Etnik Dayak Mualang - Kabupaten Sekadau. Surabaya: UNESA University Press.

Elfahmi, Woerdenbag, H. J. and Kayser, O. (2014) 'Jamu: Indonesian traditional herbal medicine towards rational phytopharmacological use', Journal of Herbal Medicine. Elsevier GmbH., 69. doi: 10.1016/j.hermed.2014.01.002.

Fitrianti, Y. et al. (2012) Etnik Gayo Desa Tetingi, Kecamatan Blang Pegayon Kabupaten Gayo Lues, Provinsi Nanggroe Aceh Darussalam. Edited by N. L. Pratiwi. Surabaya: Kanisius.

Fuadi, T. M. (2018) 'Pengobatan Tradisional Madeung dan Sale pada Ibu Masa Nifas dalam Masyarakat Aceh', Prosiding Seminar Nasional Biotik.

Green, G. et al. (2006) "We are not completely Westernised": Dual medical systems and pathways to health care among Chinese migrant women in England', Social Science and Medicine, 62(6), pp. 1498-1509. doi: 10.1016/j.socscimed.2005.08.014.

Kalangie, N. S. (1994) Kebudayaan dan Kesehatan. Jakarta: Kesaint Blanc Indah Group.

KBBI (2018) Definisi Jamu. 
Ministry of Health (2014) Riset Kesehatan Dasar 2013, Badan Litbangkes Kementerian Kesehatan RI. doi: 10.1007/s13398-014-0173-7.2.

Ministry of Health (2010) Permenkes No.003 Tahun 2010 tentang Saintifikasi Jamu Dalam Penelitian Berbasis Pelayanan Kesehatan. Jakarta.

Kristiana, L. et al. (2012) Buku Seri Etnografi Kesehatan Ibu dan Anak: Etnik Jawa Desa Gading Sari, Kecamatan Sanden Kabupaten Bantul, Provinsi Daerah Istimewa Yogyakarta. Surabaya: Pusat Humaniora, Kebijakan Kesehatan dan Pemberdayaan Masyarakat.

Mulyani, H., Widyastuti, S. H. and Ekowati, V. I. (2016) 'Tumbuhan Herbal Sebagai Jamu Pengobatan Tradisional Terhadap Penyakit Dalam Serat Primbon Jampi Jawi Jilid I', Jurnal Penelitian Humaniora, 21(2), pp. 73-91.

Paryono and Kurniarum, A. (2014) 'Kebiasaan Konsumsi Jamu Untuk Menjaga Kesehatan Tubuh Pada Saat Hamil Dan Setelah Melahirkan Di Desa Kajoran Klaten Selatan', Jurnal Terpadu Ilmu Kesehatan, 3(1), pp. 64-72.

Prastiwi, R. S. (2018) 'Pengobatan Tradisional (Jamu) Dalam Perawatan Kesehatan Ibu Nifas Dan Menyusui Di Kabupaten Tegal', Jurnal Siklus, 7(August), pp. 284-288.

Prastiwi, R. S. (2018) 'Pengobatan Tradisional (Jamu) Dalam Perawatan Kesehatan Ibu Nifas Dan Menyusui Di Kabupaten Tegal', Jurnal SIKLUS, 7(1), pp. 263-267.

Purwaningsih, E. H. (2017) 'Jamu, Obat Tradisional Asli Indonesia: Pasang Surut Pemanfaatannya di Indonesia', eJournal Kedokteran Indonesia, 1(2). doi: 10.23886/ejki.1.2065.85-89.
Purwanto, E., MJK, S. and Soerachman, R. (2015) Maparaji dalam Lingkaran Hidup: Perempuan di Desa Panyusuhan Etnik Sunda Kabupaten Cianjur. Surabaya: UNESA University Press.

Rahayu, M. et al. (2006) 'Pemanfaatan Tumbuhan Obat secara Tradisional oleh Masyarakat Lokal di Pulau Wawonii , Sulawesi Tenggara', Biodiversitas, 7(3), pp. 245-250. https://doi.org/10.13057/biodiv/d0 70310

Rustam, E., Atmasari, I. and Yanwirasti (2007) 'Efek Antiinflamasi Ekstrak Etanol Kunyit (Curcuma domestica Val.) Pada Tikus Putih Jantan Galur Wistar', Jurnal Sains dan Teknologi Farmasi, 12(2), pp. 112-115.

Sari, L. O. ruma K. (2006) 'Pemanfaatan Obat Tradisional dan Keamanannya', Majalah Ilmu Kefarmasian, III(1), pp. 1-7.

Shanthi, R. V., Jumari and Izzati, M. (2014) 'Studi Etnobotani Pengobatan Tradisional untuk Perawatan Wanita di Masyarakat Keraton Surakarta Hadiningrat', Biosaintifika, 6(2), pp. 85-93. doi:

10.15294/biosaintifika.v6i2.3101.

Silalahi, M. (2017) 'Studi Etnomedisin Di Indonesia Dan Pendekatan Penelitiannya', Jurnal Dinamika Pendidikan, 9(3), pp. 117-124.

Sri Rahayu, I., Mudatsir, M. and Hasballah, K. (2017) 'Faktor Budaya Dalam Perawatan Ibu Nifas', Jurnal Ilmu keperawatan, $5(1)$.

Triratnawati, A. (2010) 'Pengobatan Tradisional, Upaya Meminimalkan Biaya Kesehatan Masyarakat Desa Di Jawa', Jurnal Manajemen Pelayanan Kesehatan, 13(2), pp. 69-73.

Widyasari, R. et al. (2012) Buku Seri Etnograf Kesehatan Ibu dan Anak 
2012 Etnik Madura Desa Jrangoan, Kecamatan Omben, Kabupaten Sampang, Provinsi Jawa Timur. Surabaya: Pusat Humaniora, Kebijakan Kesehatan dan Pemberdayaan Masyarakat. 